\title{
ANALISIS UKURAN EFEK PENGARUH PENGGUNAAN BAHAN AJAR TERHADAP KEMAMPUAN BERFIKIR KREATIF SISWA
}

\section{ANALYSIS OF THE EFFECT SIZE TEACHING MATERIAL ON CREATIVE THINKING SKILLS}

\author{
Naurah Nazifah*, Asrizal dan Festiyed \\ Program Studi Pendidikan Fisika PPs FMIPA, Universitas Negeri Padang, Padang, Indonesia \\ "naurahnazifah13@gmail.com, asrizal@fmipa.unp.ac.id
}

Diterima: 21 Januari 2021. Disetujui: 26 April 2021. Dipublikasikan: 2 Juni 2021

\begin{abstract}
Abstrak: Revolusi industri 4.0 menuntut siswa memiliki keterampilan abad 21. Keterampilan abad 21 menuntut siswa menguasai 4C (Communication, Collaboration, Critical thinking and Creativity) yang merupakan sarana untuk mencapai kesuksesan dalam kehidupan masyarakat. Peningkatan keterampilan 4C diupayakan pemerintah melalui penyempurnaan kurikulum 2013. Sumber belajar siswa berupa bahan ajar sengaja dikembangkan untuk tercapainya tujuan pembelajaran dan meningkatkan keterampilan 4C, salah satunya keterampilan berfikir kreatif siswa. Kondisi nyata di lapangan terdapat beberapa bahan ajar yang belum mampu mendukung siswa untuk menggali dan membentuk pengetahuan sendiri dan sumber belajar belum secara keseluruhan dimanfaatkan untuk meningkatkan keteramilan berfikir kreatif siswa. Penelitian ini bertujuan untuk mengetahui pengaruh bahan ajar terhadap keterampilan berpikir kreatif siswa ditinjau dari jenjang pendidikan, materi pelajaran, jenis bahan ajar, dan peningkatan keterampilan berpikir kreatif siswa. Metode penelitian yang digunakan yaitu metode review artikel dengan mengkaji 20 artikel internasional dan nasional. Dari analisis data yang dilakukan penggunaan bahan ajar memberikan pengaruh yang berarti berdasarkan aspek jenjang pendidikan, materi pelajaran, jenis bahan ajar dan keterampilan berfikir kreatif siswa.
\end{abstract}

Kata Kunci: Artikel Review, Berfikir Kreatif, Bahan Ajar

\begin{abstract}
Industrial revolution 4.0 expected students to have 21st-century skills. 21 st-century skills require students to master 4C skills (Communication, Collaboration, Critical Thinking, and Creativity), which is a means to achieve success in people's lives. The government was striving to improve 4C skills through improving the 2013 curriculum. Teaching materials are developed learning resources for learning purposes and improving the creative thinking skills of students. However, the actual conditions in the field are that several teaching materials have not been able to support students to build and form their knowledge, and learning resources have not been optimally utilized to increase students' creative thinking ability. This study aims to see the effect of teaching materials on students 'creative thinking skills. Some studied indicators are the type of material, types of teaching materials, and improvement of students' creative thinking skills. The research method used was the article review method by reviewing 20 international and national articles. The use of teaching materials significantly affects the data analysis based on aspects of education level, subject matter, types of teaching materials, and students' creative thinking skills.
\end{abstract}

Keywords: Review Article, Creative Thinking, Teaching Materials

\section{PENDAHULUAN}

Revolusi industri 4.0 menuntut siswa untuk memiliki keterampilan abad ke-21. Abad dimana berbagai informasi tersedia dimana saja dan kapan saja sehingga diperoleh semua orang dipenjuru dunia tanpa terkecuali. Perkembangan ilmu pengetahuan dan teknoligi (IPTEK) begitu pesat, tak ada batasan ruang lagi untuk kita saling berkomunikasi. Dengan perkembangan IPTEK berimbas pada tantangan dan persaingan global yang dihadapi oleh setiap negara. Di Indonesia perlu terciptanya sumber daya manusia yang berkualitas untuk mampu bersaing dengan masyarakat luas. Dengan dasar ini, pendidikan abad ke-21 seharusnya mampu mengembangkan kompeteni pengetahuan, keterampilan, sikap dan nilai unggul [1].

Keterampilan abad ke-21 yang dimaksudkan adalah setiap orang menguasai $4 \mathrm{C}$ yang merupakan sarana untuk mencapai kesuksesan dalam kehidupan di masyarakat pada abad 21 ini. Adapun keterampilan 4C yang dimaksud adalah keterampilan Communication, Collaboration, Critical thinking and Problem Solving, dan Creativity and Innovation [2]. 4C adalah softskill yang pada implementasi kesehariannya jauh lebih bermanfaat dibandingkan dengan menguasaan hardskill [3]. Seseorang tidak memiliki keterampilan ini sejak lahir, melainkan keterampilan ini diperoleh dari proses latihan, belajar, atau pengalaman.

Salah satu keterampilan 4C yaitu Keterampilan berfikir kreatif. Berpikir kreatif merupakan aktivitas berpikir agar muncul kreativitas pada siswa, atau berpikir untuk menghasilkan hal yang baru bagi dirinya. LTSIN (2001) menyatakan bahwa ide seseorang berpikir kreatif minimal mempunyai salah satu karakteristik dari :

a. Ide itu belum ada sebelumnya

b. Sudah ada ditempat lain hanya saja ia tidak tahu 
c. Ia menemukan proses baru untuk melakukan sesuatu

d. Ia menerapkan proses yang sudah ada pada area yang berbeda

e. Ia mengembangkan sebuah cara untuk melihat sesuatu pada perspektif yang berbeda [4].

Dari kelima karakteristik berpikir kreatif tersebut, dapat disimpulkan bahwa dengan berpikir kreatif siswa dapat menemukan ide-ide yang baru atau menyempurnakan ide-ide yang sudah ada. Siswa dapat menemukan proses cara belajar atau cara menemukan gagasan yang berbeda dengan siswa lainnya sehingga siswa mampu mengembangkan suatu cara pada perspektif yang bervariasi.

Menuntut sumber daya manusia yang menguasai keterampilan abad ke-21 akan efektif jika ditempuh melalui jalur pendidikan. Perubahan kurikulum telah dilakukan oleh pemerintah. Pada jenjang sekolah telah diterapkan Kurikulum 2013 dengan berbagai perbaikannya. Kurikulum 2013 sesungguhnya telah mengakomodasi keterampilan abad ke-21, baik dilihat dari standar isi, standar proses, maupun standar penilaian [5].

Pada standar proses misalnya, Seorang guru harus menyiapkan bahan ajar yang diperlukan dalam proses pembelajaran sebelum kegiatan pembelajaran dilaksanakan. Bahan ajar ikut menentukan pencapaian tujuan pembelajaran. Bahan ajar merupakan sumber belajar yang secara sengaja dikembangkan untuk tujuan pembelajaran [6]. Bahan ajar membantu guru dalam menyampaikan materi pembelajaran dan mempermudah siswa dalam menerima pelajaran. Bahan ajar merupakan segala bahan (baik informasi, alat, maupun teks) yang disusun secara sistematis yang menampilkan sosok utuh dari kompetensi yang akan dikuasai peserta didik dan digunakan dalam proses pembelajaran dengan tujuan perencanaan dan penelaahan implementasi pembelajaran [7].

Bahan yang termuat dalam bahan ajar ini tidak hanya materi pembelajaran. Dalam bahan ajar hendaknya memiliki klasifikasi tertentu. Berdasarkan klasifikasi itulah guru memilih bahan yang akan digunakan untuk mencapai tujuan pembelajaran [8]. Jadi bahan ajar merupakan bahan yang disusun secara sistematis yang memiliki klasifikasi yang akan digunakan untuk mencapai tujuan pembelajaran. Bahan ajar memiliki beberapa bentuk sebagai berikut:

a. Bahan ajar cetak, seperti buku, handout, modul, lembar kerja siswa, brosur, leaflet, dan lain-lain.

b. Audio visual, seperti video, VCD, dan lai-lain.

c. Audio, seperti adio, kast, dan CD audio

d. Visual, seperti foto, gambar, dan model.

e. Multimedia, seperti internet.

Bahan ajar memiliki beragam jenis, ada bahan ajar cetak dan non cetak. Bahan ajar cetak yang sering dijumpai antara lain handout, buku ajar, modul, brosur, dan lembar kerja siswa. Buku ajar merupakan salah satu bentuk bahan ajar. Buku ajar harus disesuaikan dengan kebutuhan siswa, serta dilengkapi dengan petunjuk bagi guru dan siswa dengan tujuan untuk memudahkan siswa dan guru [9].

Setelah dilakukan studi awal diperoleh kenyataan yang berbeda antara kondisi ideal dengan kondisi di lapangan. Kenyataan di lapangan belum menggambarkan kondisi yang diharapkan. Studi awal telah dilakukan dalam penelitian yaitu dengan membaca dari beberapa jurnal yang berkaitan dengan penggunaan bahan ajar fisika dan IPA terhadap keterampilan berfikir kreatif siswa. Kenyataan pertama, kurikulum 2013 belum sepenuhnya terlaksana. Metode ceramah masih sering digunakan dalam pembelajaran sehingga penyampaian materi masih terfokus kepada guru. Siswa masih mengharapkan materi yang diberikan oleh guru tanpa berusaha mencari materi dari berbagai sumber belajar. Berdasarkan hasil observasi terhadap bahan ajar yang digunakan di sekolah terlihat bahwa isi dan tampilan bahan ajar kurang menarik. Konten dari bahan ajar juga belum mampu mendukung siswa untuk menggali dan membentuk pengetahuan sendiri. Akibatnya rendah nya kemampuan berpikir kreatif siswa.

Kenyataan kedua dilihat dari hasil wawancara bersama dengan guru. Penggunaan sumber belajar berupa buku teks, modul, dan LKPD. Guru di sekolah belum pernah memanfaatkan soal pengayaan pada proses pembelajaran di sekolah dikarenakan tidak adanya tidak semua sumber belajar terdapat pengayaan. Guru menyatakan bahwa jika terdapat pengayaan pada sumber belajar, hanya untuk peserta didik yang nilainya di atas Kriteria Ketuntasan Minimal (KKM). Dengan dasar itu, guru tidak pernah membahas soal pengayaan saat proses pembelajaran. Soal pengayaan menuntut siswa untuk dapat berfikir untuk mengali dan membentuk pengetahuan sendiri, sehingga siswa dapat meningkatkan kemampuan berfikir kreatif siswa, namun kenyataan disekolah sumber belajar belum dimanfaatkan secara keseluruhan.

Penelitian meta analisis dapat merangkum beberapa penelitian yang sama dan diklasifikasikan menjadi beberapa kelompok secara umum. Penelitian ini dapat dilakukan dengan beberapa alasan. Pertama, penelitian ini dapat melihat kekonsistenan dari hasilhasil penelitian yang telah dilakuakan. Kedua, penelitian ini dapat menyajikan hasil-hasil penelitian dalam cakupan yang lebih luas. Ketiga, penelitian ini dapat menentukan ukuran efek (effect size) sebuah penelitian. Keempat, penelitian ini dapat menarikan kesimpulan penelitian-penelitian yang lebih luas. Jadi meta analisis merupakan metode penelitian yang semakin populer digunakan untuk meringkas hasil penelitian-penelitian yang lebih luas.

Bertolak belakang dari penjelasan tersebut maka peneliti tertarik untuk melakukan penelitian analisis ukuran efek pengaruh penggunaan bahan ajar terhadap keterampilan berfikir kreatif siswa. Penelitian ini menganalisis beberapa penelitian yang membahas pengaruh penggunaan bahan ajar terhadap 
keterampilan berfikir kreatif. Tujuan dari penelitian ini adalah 1) menentukan ukuran efek bahan ajar terhadap keterampilan berfikir kreatif siswa berdasarkan aspek jenjang pendidikan. 2) menentukan ukuran efek bahan ajar terhadap keterampilan berfikir kreatif siswa berdasarkan aspek materi pelajaran. 3) menentukan ukuran efek bahan ajar terhadap keterampilan berfikir kreatif siswa berdasarkan jenis bahan ajar. 4) menentukan ukuran efek bahan ajar terhadap keterampilan berfikir kreatif siswa.

\section{METODE PENELITIAN}

Metode penelitian yang digunakan yaitu metode review artikel dengan mengkaji beberapa artikel pada jurnal internasional dan nasional. Meta analisis merupakan analisis statistik berupa data kuantitatif yang berasal dari sekumpulan besar hasil analisis pada sebuah penelitian individu dengan tujuan untuk mengintegrasikan ke dalam suatu kesimpulan [10]. Data dari meta analisis bersifat kuantitatif karena meta analisis menggunakan perhitungan berupa angka dan di perlukan banyak data yang tidak mungkin dilakukan dengan metode lain. Meta analisis juga dapat diartikan sebagai suatu teknik yang digunakan untuk merangkum temuan dua penelitian atau lebih dengan tujuan untuk mengga bungkan, meninjau dan meringkas penelitian sebelumnya [11]. Oleh karena itu, review artikel dapat diartikan sebagai menganalisis hasil analisis penelitian terdahulu dan merangkumnya secara kuantitatif dengan jumlah sampel yang besar.

Review artikel dilakukan dengan beberapa langkah. Langkah-langkah review artikel tersebut yaitu, menentukan dan mempelajari topik penelitian, memilih jenis publikasi artikel, mengumpulkan artikel, analisis variabel moderator, mencatat data statistik, menghitung ukuran efek, menarik kesimpulan, dan menginter pretasikan hasil review artikel [12]. Review artikel bertujuan untuk melihat seberapa besar perbedaan antar variabel atau seberapa kuat hubungan antar variabel penelitian.

Variabel penelitian merupakan suatu nilai, obek atau kegiatan yang mempunyai variasi tertentu yang ditetapkan oleh peneliti untuk dipelajari dan ke mudian ditarik kesimpulannya. Pada penelitian ini telah ditentukan tiga variabel penelitian. Ketiga variabel tersebut yaitu variabel bebas atau variabel independen, variabel terikat atau variabel dependen dan variabel moderator.

Teknik analisis di-gunakan yaitu pendekatan kuantatif. Jumlah artikel yang dianalisis adalah 20 buah artikel pengaruh bahan ajar terhadap keterampilan berfikir kreatif siswa dari tahun 2012 hingga tahun 2020. Untuk menentukan ukuran efek dari setiap data penelitian, dapat ditentukan, size menggunakan persamaan Glass, Mc Gaw \& Smith [13] yaitu:

$$
E S=\frac{\bar{x}_{\text {post }}-\bar{x}_{\text {pre }}}{S D_{\text {pre }}}
$$

Keterangan:

$\begin{array}{ll}\overline{E S} & \text { : Effect Size } \\ \bar{x}_{\text {pre }} & \text { : Nilai rata-rata pretest } \\ \bar{x}_{\text {post }} & \text { : Nilai rata-rata posttest } \\ S D_{\text {pre }} & : \text { Standar deviasi pretest }\end{array}$

Setelah effect size dihitung, selanjutnya dikategorikan pada tingkatan sebagai berikut:

Tabel 1. Kriteria Effect Size (ES)

\begin{tabular}{lll}
\hline No & ES & Kategori \\
\hline 1 & ES $\leq 0,15$ & Dapat diabaikan \\
2 & $0,15<$ ES $<0,40$ & Rendah (R) \\
3 & $0,40<$ ES $<0,75$ & Sedang (S) \\
4 & $0,75<$ ES $<1,10$ & Tinggi (T) \\
5 & $1,10<$ ES 1,45 & Sangat tinggi (ST) \\
\hline \multicolumn{3}{c}{ Efect size dengan ukuran efek kecil sebesar }
\end{tabular}

0,15 maka efeknya dapat diabaikan sedangkan ukuran efek dari 0,15 sampai 0,40 termasuk dalam kategori rendah. Ukuran efek dari 0,40 sampai 0,75 termasuk dalam kategori sedang. Ukuran efek dari 0,75 sampai dengan 1,10 temasuk kedalam kategori tinggi. Dan ukuran efek dari 1,10 sampai 1,45 termasuk kriteria efek yang sangat tinggi.

Adapun rumusan lain untuk mencari ukuran efek (effect size) adalah sebagai berikut:

1. Rerata dan standar deviasi setiap kelompok (desain: two group post test only)

$$
E S=\frac{\bar{x}_{E}-\bar{x}_{C}}{S D_{C}}
$$

Keterangan:

$\overline{E S}$ : Effect Size

$\bar{x}_{C}$ : Nilai rata-rata postest kelompok kontrol

$\bar{x}_{E}$ : Nilai rata-rata postest kelompok eksperimen

$S D_{C} \quad$ : Standar deviasi pretest

2. Rerata dan standar deviasi setiap grup (desain: two group pre-post test)

$$
E S=\frac{\left(\bar{x}_{p o s t}-\bar{x}_{p r e}\right)_{E}-\left(\bar{x}_{p o s t}-\bar{x}_{p r e}\right)_{C}}{\frac{S D_{p r e C}+S D_{p r e E}+S D_{p o s t C}}{3}}
$$

\begin{tabular}{|c|c|}
\hline$E S$ & :Harga effect size rata-rata \\
\hline $\bar{x}_{\text {pre }}$ & :Nilai rata-rata pretest \\
\hline $\bar{x}_{\text {post }}$ & :Nilai rata-rata posttest \\
\hline $\bar{x}_{\text {pre }} c$ & :Nilai rata-rata pretest kelompok kontrol \\
\hline $\bar{x}_{\text {post }} c$ & :Nilai rata-rata postest kelompok kontrol \\
\hline $\bar{x}_{p r e} e$ & :Nilai rata-rata pretest kelompok eksperimen \\
\hline $\bar{x}_{\text {post }} e$ & $\begin{array}{l}\text { :Nilai rata-rata } \\
\text { eksperimen }\end{array}$ \\
\hline$S D_{\text {pre }} C$ & $\begin{array}{l}\text { :Nilai standar deviasi pretest kelompok } \\
\text { kontrol }\end{array}$ \\
\hline$S D_{\text {post }} C$ & $\begin{array}{l}\text { :Nilai standar deviasi postest kelompok } \\
\text { kontrol }\end{array}$ \\
\hline$S D_{\text {pre }} e$ & $\begin{array}{l}\text { :Nilai standar deviasi pretest kelompok } \\
\text { eksperimen }\end{array}$ \\
\hline$S D_{\text {post }} e$ & $\begin{array}{l}\text { :Nilai standar deviasi posttest kelompok } \\
\text { Eksperimen }\end{array}$ \\
\hline
\end{tabular}

Keterangan: 
3. Jika standar deviasi tidak diketahui maka dapat dilakukan dengan uji t

$$
E S=t \sqrt{\frac{1}{n_{E}}+\frac{1}{n_{C}}}
$$

Keterangan:

ES : Effect Size

$\mathrm{t} \quad$ : Hasil Uji t

$n_{E}$ : Jumlah sampel kelompok eksperimen

$n_{C}:$ Jumlah sampel kelompok kontrol

\section{HASIL DAN PEMBAHASAN}

Pengaruh Bahan Ajar Terhadap Keterampilan Berfikir Kreatif Siswa Berdasarkan Jenjang Pendidikan

Hasil pertama dalam penelitian ini terkait pengaruh bahan ajar terhadap keterampilan berfikir kreatif siswa ditinjau dari jenjang pendidikan. Dari 20 artikel yang termasuk dalam review artikel, terdapat 10 artikel mengenai pengaruh bahan ajar fisika terhadap keterampilan berfikir kreatif siswa SMA dan 10 artikel mengenai pengaruh bahan ajar IPA terhadap ketermilan berfikir kreatif siswa. Nilai rata-rata ukuran efek terhadap keterampilan berfikir kreatif siswa dapat diperhatikan pada Tabel 3.

Berdasarkan Tabel 3 diatas dapat dideskripsikan bahwa bahan ajar memberikan ukuran efek terhadap keterampilan berfikir kreatif siswa SMA dengan rata-rata 1,09 dalam kategori tinggi dan nilai rata-rata ukuran efek terhadap keterampilan berfikir kreatif siswa tingkat SMP 1,13 yang dikategorikan sangat tinggi. Hal ini menunjukan bahwa penggunaaan bahan ajar IPA dan fisika berpengaruh terhadap keterampilan berfikir kreatif siswa.

\section{Pengaruh Penggunaan Bahan Ajar Terhadap Keterampilan Berfikir Kreatif Siswa Berdasarkan Materi Pembelajaran}

Hasil kedua meta-analisis ini terkait dengan pengaruh bahan ajar terhadap keterampilan berfikir kreatif siswa berdasarkan materi pembelajaran. Nilai rata-rata ukuran efek yang diperoleh dari materi pembelajaran diperoleh dengan menghitung e ukuran efek dari 10 artikel. Nilai rata-rata ukuran efek berdasarkan materi pembelajaran dibagi menjadi dua jenjang pendidikan yaitu SMP dan SMA. Nilai ratarata ukuran efek pengaruh bahan ajar fisika terhadap keterampilan berfikir kreatif siswa SMA ditinjau berdasarkan materi pelajaran yang digunakan dapat diperhatikan pada Gambar 1.

Dari data pada Gambar 1 dapat dideskripsikan bahwa penggunaan bahan ajar terhadap keterampilan berfikir kreatif siswa SMA berdasarkan materi pelajaran dengan nilai ukuran efek berbeda pada beberapa mata pelajaran. Pengunaan bahan ajar fisika memberikan efek sangat tinggi terdapat pada materi gelombang elektromagnetik, materi fluida dan teori kinietik gas, dan materi suhu kalor. ukuran efek penggunaan bahan ajar fisika dalan kategori sedang terdapat pada materi momentum dan implus dan materi pengukuran. Sedangkan terdapat ukuran efek dalam katerogi sedang pada materi optik geometrik.

Tabel 3. Pengaruh Bahan Ajar Dalam Pembelajaran Berdasarkan Jenjang Pendidikan

\begin{tabular}{ccccc}
\hline $\begin{array}{c}\text { Kode } \\
\text { Artikel }\end{array}$ & $\begin{array}{c}\text { Jenjang } \\
\text { Pendidikan }\end{array}$ & $\begin{array}{c}\text { Ukuran } \\
\text { Efek }\end{array}$ & $\begin{array}{c}\text { Nilai } \\
\text { Rata-rata }\end{array}$ & KET \\
\hline J1 [14] & & 0,55 & & \\
J2 [15] & & 0,82 & & \\
J3 [16] & & 0,89 & & \\
J4 [17] & & 1,45 & & \\
J5 [18] & SMA & 0,97 & & \\
J6 [19] & & 2,93 & & \\
J7 [20] & & 0,51 & & \\
J8 [21] & & 1,12 & & \\
J9 [22] & & 1,06 & & \\
J10 [23] & & 0,63 & \\
J11 [24] & & 0,56 & \\
J12 [25] & & 1,91 & \\
J13 [26] & & 1,03 & \\
J14 [27] & & 0,66 & \\
J15 [28] & & 0,97 & \\
J16 [29] & SMP & 1,16 & \\
J17 [30] & & 1,23 & \\
J18 [31] & & 1,65 & \\
J19 [32] & & 1,42 & \\
J20 [33] & & 0,72 & \\
\hline
\end{tabular}

Terdapat 10 artikel kerterampilan berfikir kreatif siswa SMP yang sesuai dengan tujuan kedua. Nilai rata-rata ukuran efek berdasarkan materi pelajaran didapatkan dari perhitungan ukuran efek dari masing-masing artikel. Nilai rata-rata ukuran efek berpikir kreatif ditinjau berdasarkan materi pelajaran yang digunakan dapat diperhatikan pada Gambar 2.

Berdasarkan data pada Gambar 2 dapat dideskripsikan bahwa penggunaan bahan ajar terhadap keterampilan berfikir kreatif siswa SMP berdasarkan materi pelajaran memiliki nilai ukuran efek berbeda setiap materi. Penggunaan bahan ajar IPA dalam kategori sangat tinggi terdapat pada materi pengukuran, pencemaran lingkungan, dan sistem organisasi kehidupan. Sedangkan penggunaan bahan ajar IPA dengan ukuran efek dalam kategori sedang terdapat pada materi getaran dan gelombang, gerak dan materi alat optik dan cahaya. 


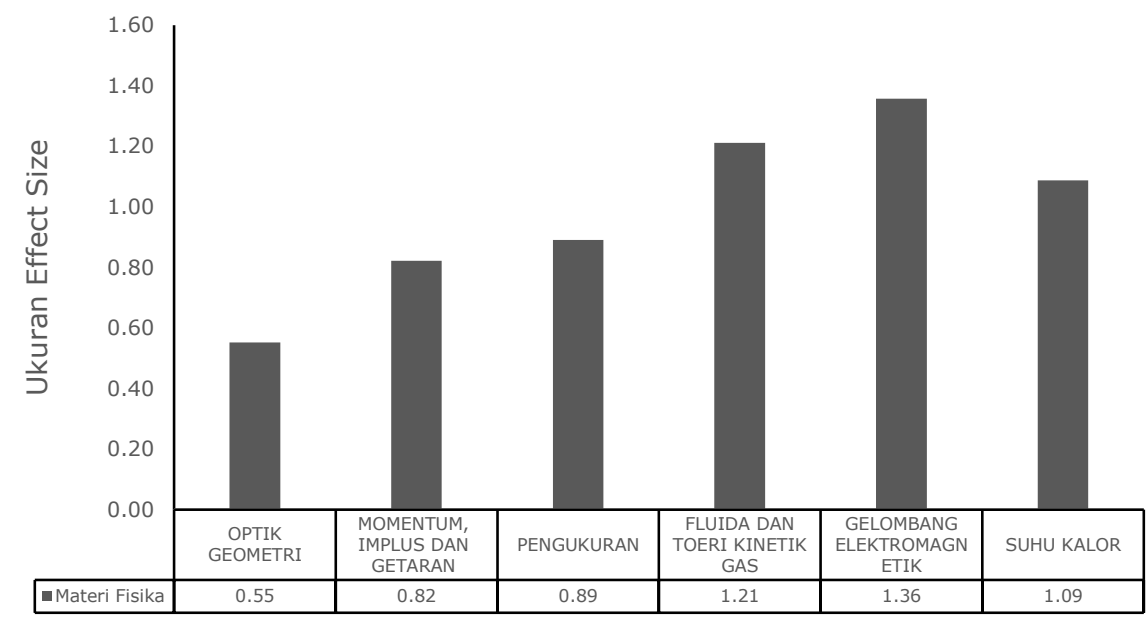

Gambar 1. Pengaruh Bahan Ajar Berdasarkan Materi Pada Jenjang Pendidikan SMA

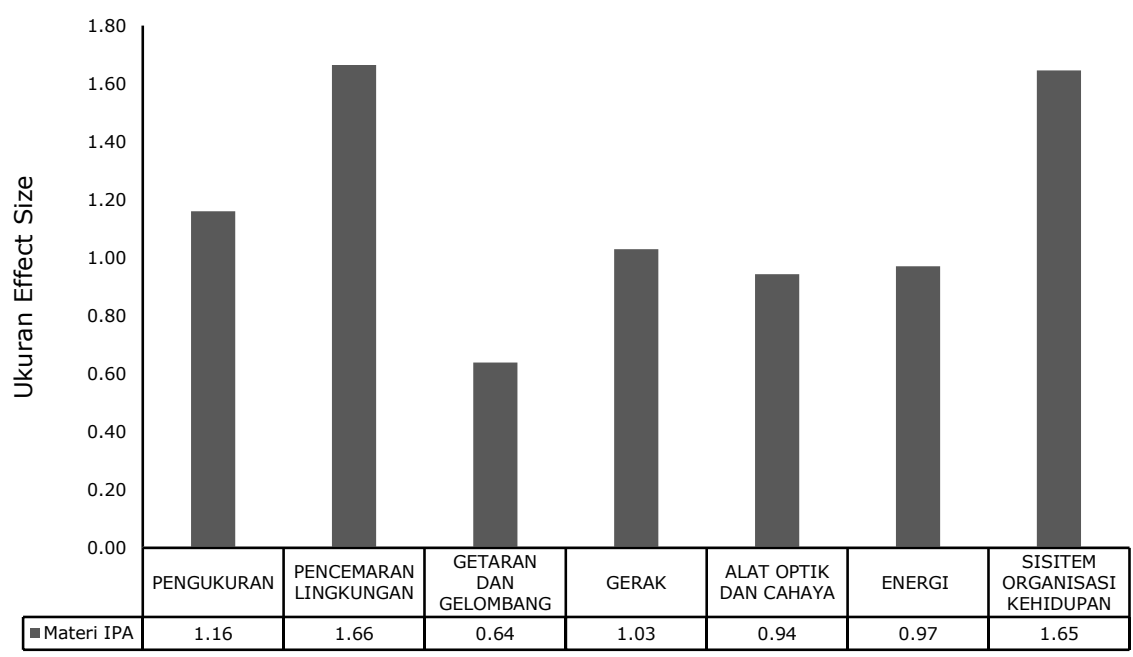

Gambar 2. Pengaruh Bahan Ajar Berdasarkan Materi Pada Jenjang Pendidikan SMP

\section{Pengaruh Bahan Ajar Terhadap Keterampilan Berfikir Kreatif Siswa Berdasarkan Jenis Bahan ajar}

Hasil ketiga dari penelitian review artikel adalah pengaruh bahan ajar terhadap keterampilan berfikir kreatif siswa berdasarkan jenis bahan ajar yang digunakan. Rata-rata ukuran efek didapatkan dari perhitungan ukuran efek pada masing-masing artikel. Nilai rata-rata ukuran efek dari 20 artikel yang dianalisis berdasarkan jenis bahan ajar yang digunakan pada Gambar 3.

Pada Gambar 3 dapat dinyatakan bahwa ukuran efek jenis bahan ajar yang digunakan terhadap keterampilan berfikir kreatif siswa memperoleh hasil yang berbeda-beda. Nilai rata-rata kategori sangat tinggi pada jenis bahan ajar LKS, bahan ajar, dan mind map. Sedangkan ukuran efek dalam kategori tinggi yaitu jenis bahan ajar modul dan ukuran efek jenis bahan ajar dalam kategori sedang adalah audio vidual. Hal ini menunjukkan bahwa penggunaan sumber belajar berupa bahan ajar cetak maupun non cetak dapat meningkatkan keterampilan berfikir kreatif siswa.
Pengaruh Bahan Ajar dalam Pembelajaran Terhadap Keterampilan Berfikir Kreatif Siswa

Hasil keempat dalam penelitian ini terkait pengaruh bahan ajar terhadap keterampilan berfikir kreatif siswa. Terdapat 20 artikel yang sesuai dengan tujuan keempat. Nilai rata-rata ukuran efek didapatkan dari perhitungan ukuran efek dari masingmasing artikel. Nilai ukuran efek pengaruh bahan ajar terhadap keterampilan berfikir kreatif dapat diperhatikan pada Gambar 4.

Berdasarkan data pada Gambar 4 dinyatakan bahwa terdapat 20 artikel dengan perolehan nilai rata-rata ukuran efek yang berbadabeda. Rata-rata keseluruhan ukuran efek penggunaan bahan ajar terhadap keterampilan berfikir kreatif yaitu 1,08. Rata-rata ukuran efek tersebut mendeskripsikan bahwa bahan ajar memberikan efek tinggi pada keterampilan berfikir kreatif siswa. Hal ini menunjukan bahwa bahan ajar efektif untuk meningkatkan keterampilan berfikir kreatif siswa. 


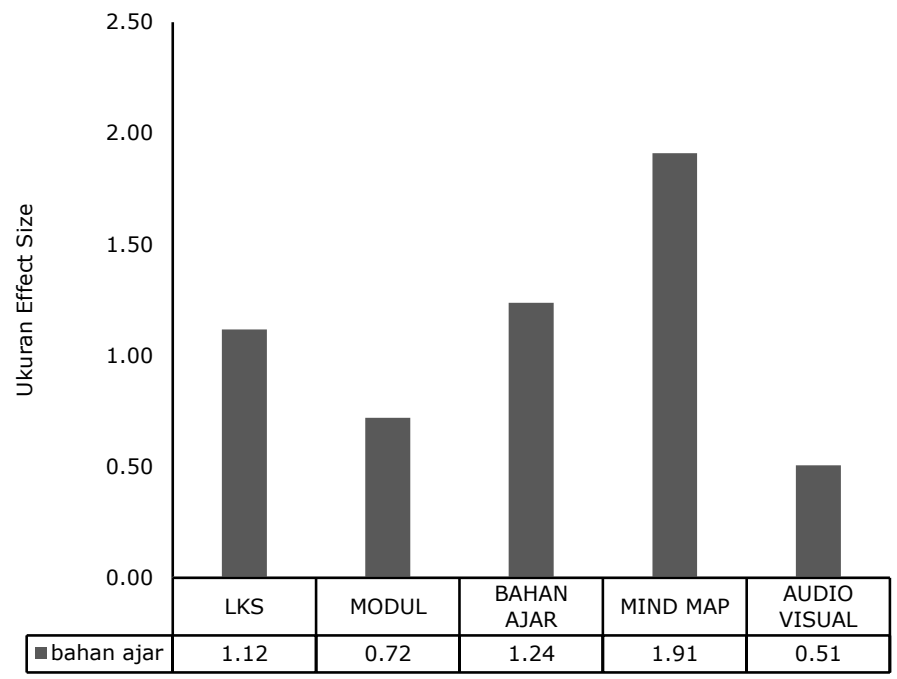

Gambar 3. Pengaruh Bahan Ajar Berdasarkan Jenis Bahan Ajar

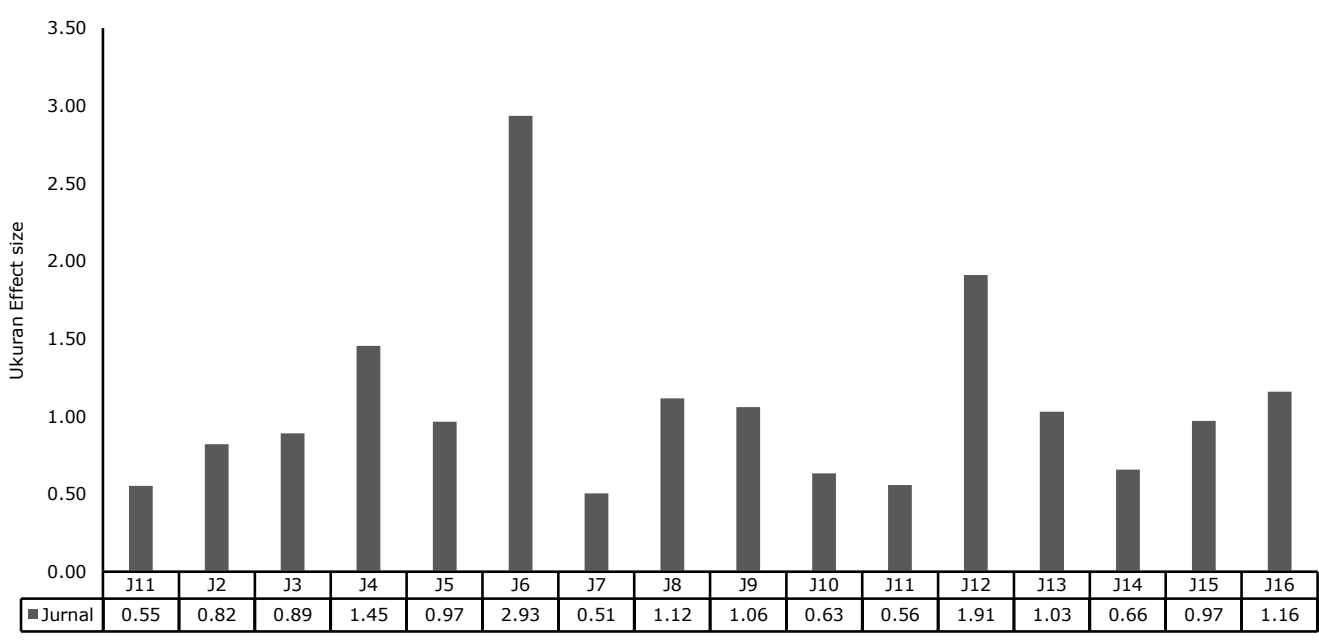

Gambar 4. Pengaruh Bahan Ajar Terhadap Keterampilan Berfikir Kreatif Siswa

Penelitian ini dilakukan untuk melihat pengaruh penggunaan bahan ajar dilihat dari beberapa variabel moderator. Setelah 20 artikel yang telah terkumpul dan dianalisis, maka didapatkan empat variabel moderator, yaitu jenjang pendidikan, materi pembelajaran, jenis bahan ajar dan keterampilan berpikir kreatif. Hasil ukuran efek dari keempat variabel yang didapatkan berbeda-beda.

Hasil penelitian pertama berdasarkan jenjang pendidikan. Bahan ajar memberikan pengaruh tinggi terhadap keterampilan berfikir kreatif siswa pada jenjang pendidikan SMP. Hal ini dikarenakan penggunaan bahan ajar pada tingkat pendidikan SMP memberikan pengaruh berarti terhadap kemampuan berfikir kreatif siswa.

Keberhasilan peningkatan kemampuan berpikir kreatif pada kelas eksperimen tidak lepas dari peranan bahan ajar sebagai sumber belajar dalam pembelajaran [34]. Selain itu, siswa yang belajar menggunakan bahan ajar lebih diarahkan untuk membentuk pola berpikir kreatif sesuai dengan aspek kemampuan berpikir kreatif. siswa yang menggunakan bahan ajar dapat menyelesaikan permasalahan yang ada dibandingkan kelas kontrol, hal ini terbukti dari nilai hasil posttest kelas eksperimen secara umum lebih tinggi dibandingkan dengan siswa kelas kontrol.

Hasil penelitian kedua berdasarkan materi pelajaran. Menurut hasil perhitungan ukuran efek, terdapat beberapa materi pembelajaran yang memiliki efek sangat tinggi terhadap keterampilan berfikir kreatif saat penggunaan bahan ajar IPA dan fisika. Keteramplan berfikir kreatif berpengaruh terhadap bahan ajar masing-masing materi, jika terdapat banyaknya pertanyaan, banyaknya jawaban, dan banyaknya ide serta banyak-nya cara disampaikan lebih kreatif oleh siswa dengan cara menyampaikan ungkapan baru. Pemikiran siswa lebih orisinil dan unik sesuai dengan keterampilan berpikir masing-masing pesertadidik [35].

Hasil penelitian ketiga berdasarkan jenis bahan ajar yang digunakan. Hasil perhitungan ukuran efek terdapat beberapa jenis sumber belajar berupa bahan ajar yang memiliki efek sangat tinggi terhadap keterampilan berfikir kreatif siswa. Sumber belajar berupa bahan ajar dapat mempermudah guru dan 
siswa dalam proses belajar mengajar [36]. Dengan bahan ajar, guru dapat mendorong dan memfasilitasi siswa dalam belajar [37].

Penggunaan bahan ajar dalam pembelajaran memberikan pengaruh yang signifikan pada kinerja siswa. Dalam kegiatan pembelajaran ada berbagai jenis bahan ajar yang dapat digunakan. Beberapa jenis bahan ajar tersebut yaitu bahan cetak (printed), bahan ajar dengar (audio), bahan ajar pandang dengar (audio visual), bahan ajar interaktif (interactive teaching material. Dari hasil yang didapatkan menunjukkan penggunaan bahan ajar yang sesuai dengan karakteristik siswa berpengaruh terhadap keterampilan berfikir kreatif siswa.

Hasil penelitian keempat pengaruh bahan ajar terhadap keterampilan berpikir kreatif. Pengaruh yang tinggi penggunaan bahan ajar terhadap keterampilan berpikir kreatif. Siswa yang belajar menggunakan bahan ajar lebih diarahkan untuk membentuk pola berpikir kreatif sesuai dengan aspek kemampuan berpikir kreatif. Siswa yang menggunakan bahan ajar dapat menyelesaikan permasalahan yang ada. Hal ini menyatakan bahwa penggunaan bahan ajar diterapkan untuk meningkat keterampilan berpikir kreatif siswa.

\section{KESIMPULAN}

Berdasarkan data yang telah dianalisis dapat diambil kesimpulan dari penelitian ini. Kesimpulan dari penelitian ini yaitu : 1) penggunaan bahan ajar terhadap keterampilan berfikir kreatif siswa memberikan pengaruh yang berarti pada aspek jenjang pendidikan. 2) penggunaan bahan ajar terhadap keterampilan berfikir kreatif siswa memberikan pengaruh yang berarti pada aspek materi pelajaran. 3) penggunaan bahan ajar terhadap keterampilan berfikir kreatif siswa memberikan pengaruh yang berarti pada aspek jenis bahan ajar. 4) penggunaan bahan ajar memberikan pengaruh yang berarti pada keterampilan berfikir kreatif siswa.

\section{DAFTAR PUSTAKA}

[1] Asrizal, A., Amran, A., Ananda, A., Festiyed, F. (2018). Development of adaptive contextual teaching model of integrated science to improve digital age literacy on grade VIII students. Journal of Physics : Conferences Series 1116032004

[2] Zubaidah, S. (2018,). Mengenal 4C: Learning and innovation skills untuk menghadapi era revolusi industri 4.0. In 2nd Science Education National Conference (Vol. 13).

[3] LTSIN. (2001). Learning teaching. Scotland: Learning and Teaching Scotland

[4] Redhana, I. W. (2019). Mengembangkan keterampilan abad ke-21 dalam pembelajaran kimia. Jurnal Inovasi Pendidikan Kimia, 13(1).

[5] Nasution,M.N,. (2010). Manajemen Mutu Terpadu (Total Quality Management), Ghalian. Indonesia : Jakarta.
[6] Asrizal, A., Festiyed, F., \& Sumarmin, R. (2017). Analisis kebutuhan pengembangan bahan ajar ipa terpadu bermuatan literasi era digital untuk pembelajaran siswa SMP kelas VIII. Jurnal Eksakta Pendidikan (JEP), 1(1), 18.

[7] Arif, M., Festiyed, F., Desnita, D., \& Dewi, W. S. (2019). Pembuatan Bahan Ajar Berbasis Android untuk Pembelajaran Fisika Pada Materi Gelombang Bunyi, Gelombang Cahaya dan Alat Optik di Kelas XI SMA/MA. Pillar of Physics Education, 12(3).

[8] Prastowo, Andi. (2011). Panduan Kreatif Membuat Bahan Ajar Inovatif. Yogyakarta: Diva Press.

[9] Widodo, Chomsin S dan Jusmani. (2008). Panduan Menyusun Bahan Ajar Berbasis Kompetensi. Jakarta: PT Elex Media Kompetindo.

[10] Aslikhah, N. (2015). Meta Analisis Dengan Effect Size Odds Ratio Pada Kasus Pengaruh Terapi Bheta-Bloker Untuk Pasien Gagal Jantung. Skripsi. UNY

[11] Mansyur \& Iskandar, A. (2017). Meta Analisis Karya Ilmiah Mahasiswa Penelitian Dan Evaluasi Pendidikan. Jurnal Scientific Pinisi, Vol. 3, No. 1. Hal 72-79

[12] Tumangkeng, Y. W., Yusmin, E., \& Hartoyo, A. (2018). Meta-Analisis Pengaruh Media Pembelajaran Terhadap Hasil Belajar Matematika Siswa. Jurnal Pendidikan Dan Pembelajaran Khatulistiwa, 7(6).

[13] Glass, G.V., McGaw B., \& Smith, M.L. (1981). Meta-Analysis in Social Research. Sage Publications. London: Sage Publications

[14] Tamami, F., Rokhmat, J., \& Gunada, I. W. (2017). Pengaruh Pendekatan Berpikir Kausalitik Scaffolding Tipe 2a Modifikasi Berbantuan LKS Terhadap Kemampuan Pemecahan Masalah Optik Geometri Dan Kreativitas Siswa Kelas XI SMAN 1 Mataram. Jurnal Pendidikan Fisika dan Teknologi, 3(1), 76-83.

[15] Hasibuan, N. S., \& Hufri, H. (2018). Pengaruh Bahan Ajar Fisika Berbasis Inkuiri untuk Meningkatkan Kemampuan Berpikir Kreatif Peserta Didik pada Materi Momentum, Impuls dan Getaran Harmonik Sederhana Kelas X SMAN 8 Padang. Pillar Of Physics Education, 11(3), 97-104.

[16] Artiwi, R. P., Asrizal, A. A., Desnita, D. D., \& Yenni, Y. D. (2020). Pengaruh E-Book Pengayaan Fisika Disertai Tugas Berita Dan Fakta Terhadap Keterampilan Berpikir Kritis Dan Kreatif Peserta Didik Kelas X Sman 2 Padang. Pillar Of Physics Education, 13(2).

[17] Krisetyaningrum, N. (2020). Implementasi Pembelajaran Fisika Materi Teori Kinetik Gas Berbasis Science, Technology, Engineering, And Mathematics (Stem) Untuk 
Mengembangkan Keterampilan Belajar Abad Ke-21 (Doctoral Dissertation, Unnes).

[18] Indriani, W. (2014). Pengaruh Penerapan LKS Berbasis Strategi Pembelajaran Peningkatan Kemampuan Berpikir (SPPKB) terhadap Keterampilan Berpikir Kreatif Siswa Kelas XI SMAN 1 Solok Selatan. Pillar Of Physics Education, 4(2).

[19] Kurniawan, T. J., \& Siswanto, J. (2012). Pengaruh Penggunakan Lembar Kerja Dengan Pendekatan Induktif Terhadap Kemampuan Berpikir Kritis Dan Kreatif Siswa Dalam Pembelajaran Fisika. Jurnal Penelitian Pembelajaran Fisika, 3(1).

[20] Siswanto, J., \& Mustofa, A. W. (2012). Pengaruh Penggunaan Model Pembelajaran Kontekstual Dengan Media Audio-Visual Terhadap Kemampuan Berpikir Kritis Dan Kreatif Siswa. Media Penelitian Pendidikan, 6(1), 1-9.

[21] Fitriani, N., Gunawan, G., \& Sutrio, S. (2017). Berpikir Kreatif dalam Fisika dengan Pembelajaran Conceptual Understanding Procedures (CUPs) berbantuan LKPD. Jurnal Pendidikan Fisika dan Teknologi, 3(1), 24-33.

[22] Novitayani, L., Sukarmin, S., \& Suparmi, S. (2016). Pengembangan Modul Fisika Berbasis Somatic, Auditory, Visual, Intellectual (Savi) Untuk Meningkatkan Kreativitas Belajar Siswa Kelas X SMA/MA Dengan Topik Kalor Dan Perpindahannya. Inkuiri, 5(2), 20-29.

[23] Dewi, S. M., Harjono, A., \& Gunawan, G. (2017). Pengaruh model pembelajaran berbasis masalah berbantuan simulasi virtual terhadap penguasaan konsep dan kreativitas fisika siswa SMAN 2 Mataram. Jurnal Pendidikan Fisika dan Teknologi, 2(3), 123-128.

[24] Hermansyah, H., Gunawan, G., \& Herayanti, L. (2017). Pengaruh penggunaan laboratorium virtual terhadap penguasaan konsep dan kemampuan berpikir kreatif siswa pada materi getaran dan gelombang. Jurnal Pendidikan Fisika dan Teknologi, 1(2), 97-102.

[25] Fitriyah, N., Hariani, S. A., \& Fikri, K. (2015). Pengaruh Model Pembelajaran Creative Problem Solving dengan Mind Mapping terhadap Kemampuan Berpikir Kreatif dan Hasil Belajar IPA Biologi. Jurnal Edukasi, 2(2), 44-50.

[26] Astutik, S., \& Prahani, B. K. (2018). Developing teaching material for physics based on collaborative creativity learning ( $\mathrm{ccl})$ model to improve scientific creativity of junior high school students. Jurnal Penelitian Fisika dan Aplikasinya (JPFA), 8(2), 91-105.
[27] Mulyadi, D. U., \& Wahyuni, S. (2016). Pengembangan media flash flipbook untuk meningkatkan keterampilan berfikir kreatif siswa dalam pembelajaran IPA di SMP. Jurnal Pembelajaran Fisika, 4(4), 296-301.

[28] Wijayanti, F., \& Widiyatmoko, A. (2015). Pengembangan LKS IPA berbasis multiple intelligences pada tema energi dan kesehatan untuk meningkatkan kemampuan berpikir kreatif siswa. Unnes Science Education Journal, 4(1).

[29] Nugraheni, D. (2018). Pengembangan lembar kegiatan siswa (LKS) berbasis inquiry materi pengukuran untuk meningkatkan kreativitas siswa. Natural: Jurnal Ilmiah Pendidikan IPA, 5(2), 98-103.

[30] Sulviana, F. (2016). Pengembangan LKPD IPA guided inquiry untuk meningkatkan produk kreativitas peserta didik SMP/MTs. Jurnal Pendidikan Matematika dan Sains, 4(1), 75-88

[31] Sari, F., Jufri, A. W., \& Sridana, S. (2017). Keefektifan Bahan Ajar IPA Berbasis Pendekatan SAVI untuk Meningkatkan Kreativitas Peserta Didik SMPN 3 Mataram. Jurnal Pijar Mipa, 12(2), 107-111

[32] Rosida, R., Fadiawati, N., \& Jalmo, T. (2017). Efektivitas penggunaan bahan ajar e-book interaktif dalam menumbuhkan keterampilan berpikir kritis siswa. Jurnal Pembelajaran Fisika, 5(1).

[33] Almuharomah, F. A., Mayasari, T., \& Kurniadi, E. (2019). Pengembangan modul fisika stem terintegrasi kearifan lokal "beduk" untuk meningkatkan kemampuan berpikir kreatif siswa SMP. Berkala Ilmiah Pendidikan Fisika, 7(1), 1-10.

[34] King, F.J., Goodson, L., M.S., dan Rohani, F., (2010), Higher Order Thinking Skills. Assessment dan Evaluation Educational Service Program.

[35] Papp, KK., Huang, G.C., Clabo, L.L.M., Delva, D., Fischer, M., Konopasek, I., Schwartzsein, R.M., dan Gusic, M., (2014), Milestones of Critical Thinking: A Developmental Model for Medicine and Nursing. Academic Medicine, Vol 89, No 5, Hal 715-720.

[36] Greenstein, L., (2012), Assessing 21st Century Skills: A Guide to Evaluating Mastery and Authentic Learning. California: Corwin

[37] Leen, C.C., Hong, K.F.F.H., dan Ying, T.W., (2014), Creative and Critical Thinking in Singapore Schools. Singapore: Nanyang Technological University. 